\title{
PHYSIOLOGICAL CHANGES WITH INDUCED HYPOTENSION PRESENT STATUS OF :CLINICAL USE
}

\author{
S/L H. H. NeILY, M.D. ${ }^{*}$
}

Throughout this Discussion "induced hypotension" refers to the intentional lowering of the blood pressure of a patient during anaesthesia and surgery in order to reduce bleeding and facilitate surgery. There have been several techniques devised to achieve this state. It is not the intention to describe these, or to discuss their relative merits, but since each alters the physiological state of the patient in varying ways it is necessary to review briefly the basic principles involved in each method.

While induced hypotension implies a drop in blood pressure and, if effective, an obvious reduction or elimination of operative bleeding, it should be kept in mind that the changes produced at the operative site are in effect: (1) a reduced volume flow of blood to the part, (2) a reduced volume capacity of blood in the part, or (3) a combination of these.

A decrease in volume flow of blood in a given part may be obtained by decreasing cardiac ouput and arterial pressure and by increasing local vascular resistance to blood flow. A decrease in the volume capacity of a part is largely. dependent on local and central venous pressure and tone. ${ }^{1}$

\section{Postural EFliects}

The posture or position of the patient during surgery, with or without induced hypotension, can influence bleeding at the operative site. It has long been known that elevation of the part being operated upon, well above the level of the rest of the body, will reduce haemorrhage. This effect is due to improved venous drainage from the part and to a reduced pressure of the blood flowing to the part. Enderby ${ }^{2}$ found that for every inch of vertical height of the operative site above heart level there is a reduction of the local blood pressure by approximately $2 \mathrm{~mm}$. $\mathrm{Hg}$, relative to the pressure at heart level. When the site is below heart level, the pressure is raised by a similar amount. This applies to both the conscious and anaesthetic state and also applies regardless of the blood pressure as recorded at heart level. If during induced hypotension the blood pressure recorded at heart level is reduced to $60 \mathrm{~mm}$. $\mathrm{Hg}$ and the operative field is elevated to 14 inches above heart level, the effect of hydrostatic pressure will result in a pressure at the operative field of only $32 \mathrm{~mm}$. Hg. This is the average pressure of blood as it enters the capillary bed in the normal state. ${ }^{3}$

While hypotension and postural ischaemia may offer real advantages. to the surgeon, the effects of these abnormal conditions on the blood supply to vital organs must be kept in mind. The techniques used to produce controlled hypo-

*Department of Anaesthesia, Queen's University, Kingston, Ontario. 
tension result in peripheral vascular dilatation. The blood pressure as read at heart level is lowered, and at the same time the compensatory mechanisms of the body for restoring blood pressure and blood flow are depressed or blocked. The effect of gravity, added to the hypotension, as in the "reverse Trendelenburg" position for head and neck surgery, may result in an inadequate cerebral circulation. One must recognize the possibility of pathological narrowing of cerebral vessels and the fact that the arterial pressure in the cerebral vessels of the patient, in the head-up position, cannot reliably be estimated from the pressure reading in the upper arm. Further, the blood flow to a part may cease or be dangerously reduced, while there is still a reașonable recordable blood pressure. This may be due to the elasticity of the walls of the smaller arteries, or to the pressure of surrounding tissues; as the intra-arterial pressure is lowered the vessels are closed by external pressure. In this way increased intracranial pressure or prolonged retractor pressure add to the risk of brain damage from cerebral anaemia during induced hypotension., ${ }^{4,5}$

It is also possible, during block of the normal reflex control of the peripheral circulation, to produce rapid fluctuations in blood pressure by changing the posture. A level of hypotension obtained while the patient is horizontal may quickly be lowered further by changing to the foot-down position in which blood tends to pool in the lower extremities, with sudden decrease in venous return to the heart. Conversely, a given degree of hypotension can often be quickly reversed by elevation of the legs to increase the venous return and cardiac output. $^{6}$

\section{Blood Volume Adjustafent}

Normal blood pressure is to a large extent the product of cardiac output and peripheral resistance, when the conditions of blood viscosity, arterial elasticity, and circulating blood volume are constant. A decrease in círculating blood volume tends to decrease blood pressure and while a small loss of volume may be compensated for by increased cardiac output and increased peripheral resistance, a large loss of volume will lead to hypotension. Controlled hypotension obtained by removal of blood (arteriotomy) was introduced by Gardner in $1946 .^{7}$ It has been largely abandoned in practice, because the conditions obtained and the risks involved are essentially those present in haemorrhagic or hypovolaemic shock.

\section{Reduction of Peripheral Vascular Resistance}

Peripheral vascular resistance in normal vessels is largely maintained and adjusted by efferent nervous stimulation carried by the sympathetic division of the autonomic nervous system. Inhibition or block of the sympathetic outflow results in loss of arteriolar tone and, when sufficiently widespread, results in a reduced blood piessure and peripheral pooling of blood. Block of the sympathetic outtlow to induce hypotension can be achieved by either of two practical methods: (1) by total subarachnoid spinal block as introduced by Griffiths and Gillies in $1948,{ }^{6}$ by total epidural block as introduced by Bromage (1951), ${ }^{8}$ or 
(2) by ganglionic blocking drugs administered intravenously. The latter group of drugs have been introduced in the past 12 years and now probably provide the most commonly used method of obtaining controlled hypotension. This group includes pentamethonium, ${ }^{9,10}$ hexamethonium, ${ }^{11}$ trimetaphan (Arfonad), ${ }^{12}$ homatropinium (trophinium). ${ }^{13}$ These drugs appear to block ganglionic transmission (parasympathetic as well as sympathetic) by raising the threshold of the ganglion cell to response to acetylcholine released at the preganglionic nerve endings. None of these drugs have any narcotic or anaesthetic effect, but they have been shown to have some neuromuscular blocking action. ${ }^{10,14,15,16}$

The popularity of these methods of inducing hypotension stems largely from the assumption proposed by Griffiths and Gillies ${ }^{6}$ that tissue oxygenation should be adequate with arteriolar dilatation and a normal flow of oxygenated capillary blood at a pressure of $32 \mathrm{~mm}$. Hg or over. However, some writers recommend that arterial pressure should not be reduced below $60 \mathrm{~mm}$. $\mathrm{Hg}$ and preferably should be higher if possible ${ }^{17,18,19,20,21}$ to allow what they feel is a safe margin, while at the same time achieving a worth-while reduction in bleeding at the operative site.

\section{Physiological Changes}

In 1952 Lynn, Sancetta, Simeone, and Scott ${ }^{22}$ reported a study of haemodynamic changes produced by spinal anaesthesia in conscious non-surgical patients. Some of their findings are pertinent to the present discussion. In regions of the body which were denervated by the spinal anaesthesia there was vasodilatation, decreased resistance to blood flow, and an increased volume capacity in the arteriolar and postarteriolar vascular beds. In areas to which the sympathetic supply was not blocked, there was vasoconstriction. Blocks which did not extend higher than the $\mathrm{T} 4$ level resulted in only moderate reductions in blood pressure, while blocks rising beyond this level were accontipanied by reductions in blood pressure which averaged 44 per cent. Small decreases in heart rate occurred which were thought to be due to decreased venous return, low right auricular pressure, and activity of the Bainbridge reflex. The decreased venous return and heart rate resulted in decreased cardiac output which, together with the decreased peripheral vascular resistance, resulted in hypotension. Left ventricular work was reduced by an average of 75 per cent in their subjects with high spinal blocks. In 1956 Hackel, Sancetta, and Kleinerman ${ }^{23}$ reported a study of the effect of hypotension produced by subarachnoid block on the coronary blood flow and myocardial metabolism in man. Decreased coronary blood flow and decreased myocardial oxygen consumption were noted. At the same time extraction of oxygen from the coronary blood by the myocardium was not increased, indicating myocardial oxygenation to be adequate for the lower work load. However, this does not imply a reduced risk of myocardial ischaemia since, at low blood pressure levels, perfusion of coronary arteries narrowed by disease may be excessively reduced. The coronary arteriovenous differences for glucose, lactate, and pyruvate were not changed during the period of hypotension, indicating normal myocardial metabolism. 
Other haemodynamic changes associated with induced hypotension were reported in 1954 by Van Bergen, Buckley, French, Dobkin, and Brown. ${ }^{24}$ Ganglionic blockade was obtained with hexamethonium, 25-50 mg., and, although a control study was not done, it was felt that general anaesthesia contributed to some extent to the blood pressure drop. As might be expected, a change in posture from supine to a head-up tilt produced a further fall in blood pressure. Hypertensive patients had a relatively greater blood pressure drop than normotensive patients. One patient in "normovolaemic shock" and another in compensated hypovolaemic shock had profound reductions in blood pressure. During ganglionic blockade central venous pressure was reduced and further reduction was demonstrated on change to the foot-down position. Intermittent positive pressure respiration had little effect, unless the mean intrapulmonary pressure was high and sustained. The characteristic initial blood pressure response of the normal conscious subject and the patient under light anaesthesia to hypoxia or hypercarbia is an elevation. These workers found that, after hexamethonium, hypoxia for four minutes produced a further slight fall in blood pressure, while hypercarbia of five minutes' duration produced no change. All the various findings noted above are evidence of haemodynamic changes to be expected during blockade of the sympathetic nervous system.

The risk of myocardial ischaemia is of particular concern during hypotension. Electrocardiographic monitoring has been found a useful guide during induced hypotension and reports have been published noting significant ECG changes. $^{25.216}$ Rollason and Hough (1959) ${ }^{26}$ made a detailed study of 52 surgical patients using ECG monitoring during hypotension induced with ganglionic blocking agents. The systolic blood pressures during the hypotensive periods in most of their cases were less than 50 per cent of the preoperative level. ECG evidence of myocardial ischaemia was noted in 19 of their cases, the evidence being ST segment depression and/or T-wave changes. In only 6 cases did ST segment and $\mathrm{T}$-wave changes occur together. There was no clear correlation between the lowest systolic pressures and the ECG changes seen and this led these writers to suggest that myocardial blood supply remained adequate during hypotension for the reduced cardiac work load.

In all cases in which ECG changes were noted the picture reverted to that present preoperatively and no patient sustained any permanent heart injury. Such findings as these, as well as long experience, led Gillies ${ }^{20}$ to conclude that "induced hypotension is not dangerous to a healthy heart so long as (1) the mean arterial pressure is not allowed to fall below a critical level which differs with individuals, but in any case must not be. lower than $60 \mathrm{~mm} . \mathrm{Hg}$, and (2) effective pulmonary ventilation is maintained." The indication for ECG monitoring during hypotensive anaesthesia is obvious.

\section{Halothane}

Since at least one report of halothane-oxygen anaesthesia for controlled hypotension has appeared in the literature (Murtagh 1960) ${ }^{51}$ it is necessary to mention briefly the haemodynamic effects of this agent. Halothane causes a drop in blood 
pressure through a combination of several pharmacological effects. It has been shown to cause a direct depression of the myocardium ${ }^{27}$ and a parasympathomimetic effect on the conducting system of the heart, leading to bradycardia ${ }^{28,29}$ These together cause a decrease in cardiac output. There is a reduction in peripheral vascular tone due to vasomotor centre depression, ${ }^{30}$ a direct relaxant effect on the vessels themselves, ${ }^{31}$ and possibly a ganglionic blocking effect as well. ${ }^{32}$ Indirectly, halothane anaesthesia may contribute further to a blood pressure drop through its depression of respiration. As this effect on respiration is corrected by assistance to or control of respiration, using intermittent positive pressure, venous return may be reduced and cardiac output further diminished.

\section{HyperveNTILATION}

Use of intermittent positive pressure respiration to elevate the mean intrathoracic pressure and reduce venous return has been made to augment some techniques of controlled hypotension. ${ }^{19}$ For this purpose, controlled respiration is effective and apparently in itself is harmless, as judged by clinical results. Robinson and Gray ${ }^{33}{ }^{34}$ reported on studies made during passive hyperventilation of conscious volunteers and anaesthetized patients. Although none of these subjects were at the same time made hypotensive, their findings would seem to indicate that the elevated blood $\mathrm{pH}$ and lowered $\mathrm{pCO}_{2}$ are not harmful in themselves. Marked peripheral vasoconstriction was noted in the conscious subjects but not in the anaesthetized patients. In 1962 Allen and Morris ${ }^{35}$ reported their findings in critical flicker fusion tests in surgical patients, after anaesthesia that included hyperventilation for periods of one to over four hours. In a series of 21 patients, positive test results indicating cerebral damage were obtained in 17 . In all of these the test reverted to normal within three days. In a control series who were not hyperventilated, all flicker fusion tests were negative. In 1957 Berg, Nilson, and Vinnars ${ }^{36}$ reported an investigation dusing the same test in a series of 73 surgical patients subjected to induced hypotension for 20 to 90 minutes during anaesthesia. In approximately 50 per cent the test results were positive, suggesting some degree of diffuse cerebral injury. In all cases the injury was considered slight and transient; all reverted to normal in a matter of days. It was felt that a level of blood pressure below $80 \mathrm{~mm}$. $\mathrm{Hg}$, in combination with the foot-down position, considerably increases the risk of cerebral injury. It is quite conceivable that, had hyperventilation been added to the technique of management, the incidence of positive results might well have been much higher.

\section{LIVER}

The effects of hypotension produced by ganglionic blocking agents and by high spinal anaesthesia on the liver and kidneys have been studied. In the normotensive state about 20 per cent of the hepatic blood supply is from the hepatic artery and about 80 per cent is from the portal venous system. The small arterial supply is at normal arterial oxygen saturation while the portal venous 
blood has an oxygen saturation of about 85 per cent. ${ }^{37}$ Mueller, Lynn, and Sancetta ${ }^{38}$ found that during the hypotension of high spinal anaesthesia the hepatic blood flow is reduced by 33 per cent, and the brachial artery-hepatic venous, oxygen difference is increased. The increased extraction of oxygen from the splanchnic blood was thought to be due to the more prolonged contact between the blood circulating in this bed and the tissue cells. When the circulation in the splanchnic region is slowed excessively, the risk of hypoxic damage to the liver and failure of liver function is great. In 1954 Greene et al. ${ }^{39}$ reported on alterations found in liver function during hypotensive spinal anaesthesia given to patients under general anaesthesia. It was found that bromsulphalein retention occurred postoperatively in all cases and was particularly marked in patients who had some preoperative liver disease. The retention was most marked on the day after the operation and gradually subsided over a period of several days. There was no correlation between the degree of hypotension and the degree of postoperative bromsulphalein retention. These workers point out that these changes in bromsulphalein retention are similar in degree and duration to those found following operations performed under normotensive anaesthesia. The reason seemed to be that during cyclopropane, ether, or thiopentone anaesthesia, the decrease in hepatic blood flow was greater than occurred during high spinal anaesthesia. The decreased hepatic blood flow during general anaesthesia appeared to be due primarily to splanchnic vasoconstriction.

\section{KIDNEY}

The formation of urine by the kidney is by a combination of glomerular filtration and tubular reabsorption. These are chiefly dependent on arterial blood pressure and renal blood flow. It has been found that at blood.pressures of approximately $70 \mathrm{~mm} . \mathrm{Hg}$, and below, glomerular filtration and urine output are reduced. Morris et al. ${ }^{40}$ studied renal haemodynamics during hexamethoniuminduced hypotension and found that at blood pressures averaging 65 per cent of control the glomerular filtration rate was reduced 74 per cent initially, rose slightly, but fell again during three hours of hypotension. The renal plasma flow (indicative of renal blood llow $_{\mathrm{b}}$ ) also showed an initial fall to 74 per cent of control but thereafter gradually rose, until it exceeded the control figure at the end of three hours. During this period the urine output averaged less than 20 per cent of control. These workers concluded that there was little danger of renal anoxia in the supine patient with blood pressures as low as $55 \mathrm{~mm}$. $\mathrm{Hg}$.

Lynn, Sancetta, Simeone, and Scott studied renal function during hypotensive spinal anaesthesia. ${ }^{22}$ They found no change in concentration-dilution and BSP tests. There was a consistent reduction in the rate of urine output. The average preoperative flow of urine, in the patients who received high spinals, was 1.99 c.c. per min. and this average fell to 0.09 c.c. per min. during the period of anaesthèsia. Evans and Enderby ${ }^{41}$ compared urinalysis of 50 control patients who had undergone surgery without hypotension with 50 patients who, had had hexamethonium-induced hypotension. All were normal preoperatively. The results 
showed a slightly greater incidence of proteinuria, casts, and red cells in the urine of patients who had had induced hypotension. The conclusion was that if renal function is normal before operation, it is unlikely to be appreciably impaired after recovery from hypotension produced by hexamethonium.

\section{BraIN}

As the brain, of all the tissues of the body, is the most sensitive to lack of oxygen and since controlled hypotension has frequently been used for intracranial surgery, considerable study has been carried out regarding this organ. Greene et $a l_{.39}$ conducted preoperative and postoperative psychomotor tests on 35 surgical patients given hypotensive spinal blocks. Of 25 patients for whom the studies were completed, five patients showed definite and consistent signs of mental impairment, both by quantitative test results and clinical signs. These workers were not convinced that hypotension was entirely responsible for these changes, since similar changes were noted in other patients who had undergone surgery without hypotension. Alteration of cerebral haemodynamics during induced hypotension in conscious patients has been investigated by a number of different groups. Morris, et al. ${ }^{40}$ gave hexamethonium to unanaesthetized horizontally supine patients. In a group of eight patients the blood pressure drop averaged 39 per cent of the control readings. Cerebral blood How decreased 30 per cent and cerebral vascular resistance decreased 11 per cent. The cerebral arteriovenous oxygen difference increased by 29 per cent, indicating increased oxygen extraction from the reduced blood supply. There was a 12 per cent reduction in cerebral oxygen consumption. This would seem to indicate that in the conscious patient there is almost complete compensation for the reduced cerebral blood flow accompanying blood pressure drops down to approximately 60 per cent of normal. Bromage ${ }^{42}$ noted EEG changes typical of cerebral hypoxia, as well as coma and convulsions, in unanaesthetized volunteers during pentamethoniuminduced hypotension and reverse-Trendelenburg position. Saunders ${ }^{43}$ made observations of cerebral blood flow and oxygenation in eight patients undergoing craniotomy with ether-oxygen anaesthesia and controlled hypotension while horizontal or nearly so. The arteriovenous oxygen difference observed was 4.8 vol. \% (which was less than the normal of 6.2 vol. \%). ${ }^{3}$ The cerebral blood flow was found to be about equal to that of the normal person. This would indicate that under these conditions the cerebral blood flow remains more than adequate to meet the metabolic demands of the brain. This is partly due to decreased cerebral vascular resistance brought about by hexamethonium-bromide-induced ganglionic block and partly to a reduced cerebral oxygen demand during anaesthesia. Saunders concluded that "cerebral blood flow and oxygenation remain adequate during hypotension when the patient is kept horizontal or nearly so, and care is taken that the 'systolic blood pressure is not lowered below 55 to $60 \mathrm{~mm}$. Hg." Essentially similar results were obtained and similar conclusions were drawn by Hughes. ${ }^{44}$

Evidence of cerebral hypoxia or ischaemia is readily shown by a change in EEG tracings. The normal alpha rhythm may initially change to one of slow 
waves of high amplitude, which later change to slow waves of low amplitude, and finally all evidence of electrical activity ceases. ${ }^{45}$ Since actual blood pressure levels have been found to be somewhat unreliable as an indication of peripheral blood How, EEG monitoring can be a useful guide, particularly in cases in which a head-up tilt is necessary or in which there may be some other cause for possible cerebral ischaemia.

Induced hypotension has been widely used in intracranial surgery. In this area its use has been found effective in producing a reduction in intracranial tension as well as reduced bleeding. There are three components which, within the rigid cranium, contribute to the total intracranial tension-the parenchymal component, the cerebrospinal fluid as contained within the ventricles and subarachnoid spaces, and the vascular component which includes the arterial, capillary, and venous beds within the cranium. Intracranial tension is rapidly increased by vasodilatation and arterial hypertension, for example, as produced by hypoxia or by some impediment to venous return from the head. There is some suggestion that cerebrospinal fluid volume also is increased at the same time. Induced hypotension reduces the vascular component and may in time reduce the volume of cerebrospinal fluid. ${ }^{ \pm 6}$

\section{Adrenal Medulla}

As noted earlier the more commonly used techniques for producing hypotension involve a block of the sympathetic nerve supply to peripheral vessels. Since the output of adrenaline and noradrenaline by the adrenal medulla is controlled by sympathetic nerve supply via the splanchnic nerves, it is to be expected that the normal response of the adrenal medulla to anaesthesia, operative trauma, and pain, and to a fall in blood volume and blood pressure, will be reduced or blocked when the sympathetic outflow is blocked. During total spinal block all sympathetic efferent innervation is blocked and with it the output of adrenaline and noradrenaline by the adrenal medulla is stopped. It has been found that while ganglionic blocking agents do interrupt sympathetic outlow at the ganglia they may have little effect on the sympathetic innervation of the adrenal medulla. ${ }^{47}$ In any case the haemodynamic response initiated by the sympathoadrenal system during operative trauma, blood loss, pain, etc., i.e., peripheral vasoconstriction and restricted circulation, is reduced or absent during induced hypotension produced by these techniques used in conjunction with general anaesthesia. The net result of this appears to be an increased iolerance for the stress of surgery, blood loss, and hypotension. Some writers feel that this effect is a distinct advantage of induced hypotension, quite apart from the advantages of reduced bleeding and improved operating conditions. ${ }^{48} 49$

\section{Current Status of Clinical Use}

Some idea of the current status of induced hypotension is obtained from a review of the published reports of the past three years. This is obviously a very limited view because most of the reports concerning large numbers of cases seem 
to be those published by British and European groups. There is little published evidence in the American or Canadian anaesthesia literature to indicate that induced hypotension is frequently used.

Sheppard, ${ }^{49}$ in 1961, reported a series of 2000 retropubic and transurethral prostatectomies, 1688 of which were performed during induced hypotension. There was no selection of patients; many were treated as emergencies. Almost all were given hexamethonium after induction of anaesthesia and were placed in a Trendelenburg position. The blood pressure was maintained between 90 and 100 $\mathrm{mm}$. Hg systolic and any drop below this level was countered with dextran infusion rather than with vasopressors. At the end of the procedure there was no attempt to restore the blood pressure to normal; rather the prolonged action of hexamethonium and the hypotension were considered advantageous, in that reactionary haemorrhage was markedly reduced. There was no evidence of shock. and the operating conditions for the surgeon were markedly improved. In 248 cases operated on without hypotension 37 per cent received an average of one unit of blood. In the 1688 cases with induced hypotension 7.2 per cent received an average of one unit of blood. Only in five instances was blood given in the operating room, most being given 3 to 4 days after operation. The author compared his mortality figures with those of two other series recently reported and found no significant difference, particularly regarding deaths from cerebrovascular and cardiovascular complications. The closing paragraph states: "It is suggested that the mortality figures in this series show no increase due to the induced hypotension used throughout the series. Indeed, taking into account the greater numbers of cases in the older age groups, it may be that induced hypotension affords more protection against pre-existing myocardial disease than other methods."

Linacre, ${ }^{48}$ in 1961, reviewed a series of 1000 cases of major gynaecological surgery which included induced hypotension. The list contained all forms of major gynaecological surgery from pelvic repair to Werthein hysterectomy. Most of the patients were of middle age and 11 per cent were over 70 years of age. Hexamethonium was the usual hypotensive agent used, the intention being to reduce the blood pressure to the region of 70 to $75 \mathrm{~mm}$. Hg. Patients were kept in $10^{\circ}$ to $12^{\circ}$ head-down position during surgery and postoperatively, until the systolic blood pressure had increased spontaneously to $90 \mathrm{~mm}$. Hg. Blood pressure drops below the desired level were reversed with intravenous saline or dextran in preference to vasopressor drugs. The advantages reported were better and more rapid surgery, less need for blood transfusion since blood loss is minimal, and a significantly reduced complication rate, including less postoperative haemorrhage in comparison with another series in which induced hypotension was not used. The author observed that the general condition of the patients during the early postoperative period was strikingly good, and protection against operative shock was felt to be a valuable feature.

In 1960 Moersch, Patrick, and Clagett ${ }^{50}$ reviewed a series of 197 radical mastectomies performed during induced hypotension and compared these with a control group of 129 patients. Hexamethonium and trimetaphan were the hypotensive agents used, and the patients who received the former were given 
vasopressors at the end of the procedure to return the blood pressure toward normal. This practice was not found to increase bleeding. It was found that the average total blood loss in the hypotensive series was $495 \mathrm{ml}$., while in the control series it was $728 \mathrm{ml}$.

Murtagh ${ }^{51}$ reported two small series of $25 \mathrm{ENT}$ and 30 thoracic operations in which the anaesthetic and controlled hypotension were provided with halothane vapourized in oxygen, supplemented only with controlled respiration. It was found that a four-litre flow of oxygen per minute, with small increments of halothane, gave the best control of anaesthetic depth and blood pressure level.

Bozza, Maspes, and Rossanda ${ }^{46}$ studied the relative effectiveness of various measures used to reduce brain volume and tension during 330 intracranial operations. It was pointed out that whereas in 1953 induced hypotension was used in 50 per cent of their cases, in 1958 and 1959 it was used in less than 10 per cent. In many of the latter it was used in conjunction with other measures known to be effective in lowering intracranial tension and brain volume. Such techniques as hyperventilation, hypothermia, and the osmotic diuretics have been found equally or more effective and much safer than induced hypotension. The indication for induced hypotension may be more specific when the intracranial surgery involves the risk of troublesome haemorrhage; but even in this situation hypothermia and a brief period of carotid occlusion may be more effective and, according to Vandewater, ${ }^{52}$ provide better operating conditions and a lower risk to the patient.

Tappura, Statis, and Troupp ${ }^{53}$ reviewed a series of 482 cases of intracranial surgery in which induced hypotension was used. Their conclusion was that induced hypotension with Arfonad is a comparatively safe and reliable method but may be used for brief periods only. If a time-consuming procedure is expected and the surgeon needs optimum conditions all the time, hypothermia, controlled respiration, and removal of cerebrospinal fluid are preferable.

The largest single series is 9,107 hypotensive anaesthetics, reported by Enderby ${ }^{54}$ in 1961. He records nine fatalities, of which four, or possibly five, were caused by inadequate ventilation during the hypotensive period. There were three cardiac arrests, one of which was successfully resuscitated. Cerebral thrombosis occurred once in this series, The results of this series are indeed remarkable when compared with those reported in a monograph by Little ${ }^{4}$ published in 1956.

\section{SUMMARY}

It would appear from recently reported series that the technique of induced hypotension is now being used more freely in some types of surgery, in which it was not formerly used, or for which it was not originally conceived. It is also noted that induced hypotension has fallen into disfavour for certain types of intracranial surgery. As experience with induced hypotension has accumulated, the indications for its use appear to have changed. As stated by Little in 1962,55 "very few of these operative procedures on very few of the patients would satisfy the rigid criteria that the indications for the use of the hypotensive techniques must consist in the probable failure either of the patient to survive the operation, or of the surgery to be completed successfully, without the use of induced hypo- 
tension." It would appear that the technique is currently being used to achieve minimal bleeding; easier, more rapid, and safer surgery; minimal need for blood replacement; and an increased tolerance for the stress of surgery and anaesthesia. It is debatable whether these gains justify the risks involved in many of the patients who come to surgery.

\section{RÉSUMÉ}

L'hypotension provoquée suppose une chute de la pression artérielle, une diminution ou une absence de saignement durant l'opération. Il ne faut pas perdre de vue les changements observés au site opératoire: (1) débit sanguin diminué au site opératoire, (2) diminution de la capacité du volume sanguin à ce site, (3) un mélange des deux facteurs.

Une diminution du débit sanguin dans un endroit donné peut être obtenue en diminuant le débit cardiaque et la pression artérielle et en augmentant la résistance vasculaire locale au courant sanguin.

La position du malade durant la chirurgie peut modifier le saignement du site opératoire. L'élévation du site opératoire beaucoup au-dessus du reste du corps va diminuer l'hémorragie en facilitant le retour du sang veineux du site opératoire et en diminuant la pression artérielle à cet endroit. Enderby ${ }^{2}$ a trouvé que, pour chaque pouce en hauteur verticale du site opératoire au-dessus du niveau du coeur, il existait une diminution de la pression sanguine locale d'à peu près $2 \mathrm{~mm}$. Hg comparée à la pression au niveau du coeur. Au cours de l'hypotension provoquée, sì, au niveau du coeur, la pression sanguine est abaissée à $60 \mathrm{~mm}$. $\mathrm{Hg}$ et que le site opératoire est 14 pouces plus haut que le coeur, l'effet de la pression hydrostatique remènera donc la pression au site opératoire à $32 \mathrm{~mm}$. $\mathrm{Hg}$. C'est la pression moyenne du sang lorsqu'il entre dans le lit capillaire à l'était normal. ${ }^{3}$

Il ne faut pas perdre de vue les effets de l'hypotension et de l'ischémie posturale sur l'apport sanguin aux organes vitaux. Les techniques employées pour produire l'hypotension contrôlée visent en même temps à déprimer ou à bloquer les mécanismes compensateurs de l'organisme qui tendent à rétablir la pression et le débit sanguin. Si, en plus de l'hypotension, on élève la tête du malade, il peut s'ensuivre une circulation cérébrale inadéquate. Il fáut admettre que, lorsque la. tête est élevée, la pression sanguine dans les vaisseaux cérébraux ne peut pas être appréciée d'après la pression trouvée au membre supérieur.

Dans un endroit de l'organisme, le débit sanguin peut être nul ou dangereusement réduit alors qu'on peut prendre ailleurs une pression sanguine convenable. Une pression intracranienne augmentée ou une pression prolongée par un écarteur augmentent le risque de dommage cérébral d'origine ischémique au cours de l'hypotension provoquée. ${ }^{4,5}$

L'hypotension peut être produite en diminuant le volume de sang circulant. Cette façon de produire l'hypotension contrôlée a été pratiquement abandonnée' parce qu'elle comporte les mêmes risques que les chocs hémorragiques ou hypovolémiques.

L'inhibition ou le blocage des influx sympathiques entraîne une diminution de la pression sanguine et une stagnation sanguine périphérique. De cette façon, on 
peut produire une hypotension par̂ l'une ou l'autre des méthodes suivantes: un blocage rachidien subarachnoïdien ou un blocage épidural ou en administrant, par voie endoveineuse, des médicaments ganglioplégiques. La popularité de ces méthodès d'hypotension provoquée a grandi à la suite de l'affirmation faite par Griffith et Gillies ${ }^{6}$ que l'oxygénation devrait être adéquate lorsqu'il existe une dilatation artériolaire, un débit normal de sang oxygéné à une pression de $32 \mathrm{~mm}$. Hg ou plus.

Au cours de l'hypotension, ce qu'il y a de plus à craindre: c'est l'ischémie du myocarde. La littérature contient des cas où l'on a observé des modifications importantes du tracé électrocardiographique., ${ }^{25,26} \mathrm{Il}$ semble qu'il n'existe pas de corrélation exacte entre les plus basses pressions systoliques et les changements électrocardiographiques et l'on prétend que, au cours de l'hypotension, l'apport sanguin au myocarde demeure adéquat pour le peu de travail que le cœur a à faire.

On s'est servi du fluothane pour produire l'hypotension/contrôlée. Cet agent entraîne une chute de pression parce qu'il produit une dépression directe sur le myocarde et un effet parasympathicomimétique sur le système de conduction du coeur, entraînant une bradycardie. Il existe une diminution du tonus vasculaire périphérique à la suite de la dépression vasomotrice, un effet dilatateur direct sur les vaisseaux eux-mêmes et, peut-être, un effet ganglioplégique. L'anesthésie au fluothane peut aussi entraîner une diminution de la pression sanguine par ses effets dépresseurs sur la respiration.

L'emploi de la respiration à pression positive intermittente pour augmenter la pression intrathoracique moyenne et diminuer le retour du sang veineux est également courant pour compléter les techniques d'hypotension contrôlée.

Lorsque la circulation est. trop ralentie dans la région splanchnique à cause de l'hypotension, il existe un risque de dommage hépatique par hypoxie et la fonction hépatique peut être menacée.

Des recherches sur le débit sanguin rénal et la filtration glomérulaire au cours de l'hypotension contrôlée permettent d'affirmer que si la fonction rénale était normale avant lopération, selon toute vraisemblance, elle ne sera pas sérieusement modifiée à la fin de l'hypotension. Toutefois, chez les malades qui ont été soumis à l'hypotension, on trouve plus souvent dans les urines: de l'albumine, des cylindres et des globules rouges.

L'on sait que le cerveau est le tissu le plus sensible au déficit en oxygène et puisque l'on se sert d'hypotension contrôlée fréquemment au cours de la chirurgie cranienne, de nombreuses études ont été entreprises pour apprécier les effets de l'hypotension sur le cerveau. L'hypotension contrôlée s'est avérée efficace pour diminuer la tension intracranienne et les pertes de sang. L'hypotension contrôlée diminue le volume vasculaire du contenu cranien et, à l'occasion, peut même diminuer le volume du liquide céphalo-rachidien cérébral. Saunders en vient à la conclusion que ${ }_{f:}$ durant l'hypotension, si l'on maintient le malade en position horizontale ou à peu près, le débit sanguin cérébral et l'oxygénation demeurent adéquats pourvu que la tension artérielle ne baisse pas au-dessous de $55-60 \mathrm{~mm}$ Hg." 2

Au cours de l'hypotension employée pendant l'anesthésie générale, la réponse 
homéostatique amorcée par le système sympatho-surrénalien au traumatisme opératoire est bien affaiblie ou absente. Le résulta.t final de cette association est ceci: selon toute apparence, le malade acquiert une tolérance accrue au stress qu'occasionnent la chirurgie, la perte de sang et l'hypotension; à part l'avantage de diminuer les pertes sanguines, cette façon d'agir apporte ce facteur additionnel.

La littérature récente nous présente des séries de malades opérés avec cette technique d'hypotension provoquée et, selon toute apparence, on l'emploierait de plus en plus couramment dans certaines opérations où on ne l'employait pas antérieurement ou, du moins, pour lesquelles on ne la destinait pas. On apprend également que, pour certaines sortes de chirurgie intracranienne, cette hypotension provoquée est complètement abandonnée. A mesure qu'augmente l'expérience avec l'hypotension provoquée, l'on semble en modifier les indications. Il semblerait que les buts de son usage sont: diminuer les pertes sanguines, rendre la chirurgie plus facile, plus rapide et moins risquée, réduire au minimum les transfusions et augmenter la tolérance à la chirurgie et à l'anesthésie. II demeure discutable si ces avantages compensent pour les risques encourus chez un bon nombre de malades qui recourent à la chirurgie.

\section{REFERENCES}

1. Greene, B. A., Goffen, B. S.; Behkowitz, S.; \& Katz, J. Excessive Operative Bleeding due to Anaesthesia. New York State J. Med. 61, 3802 (1961).

2. Enderby, G. E. H. Postural Ischaemia and Blobd Pressure. Lancet i: 183 (1954).

3. Keele, C. A. \& Neil, E. Samson Wright's Applied Physiology, 10th ed., p. 17. London: Oxford University Press (1961).

4. Lrtile, D. M. "Controlled Hypotension" in Anaesthesia and Surgery, 1st ed., p. 78. Springfield, Ill.: Charles C. Thomas (1956).

5. Aserman, D. Controlled Hypotension in Neurosurgery with Hexamethonium and Procaine amidi. Brit. Med. J. 1: 961 (1953).

6. Griffiths, H. W. C. \& Gillies, J. Thoraco-lumbar Splanchnicectomy and Sympathectomy; Anaesthetic Procedure. Anaesthesia 3: 134 (1948).

7. Gardner, W. J. The Control of Bleeding during Operation by Induced Hypotension. J.A.M.A. 1.32: 572 (1946).

8. Bromage, P. R. Vascular Hypotension in 107 Cases of Epidural Analgesia. Anaesthesia 6: 26 (1951).

9. Enderby, G. E. H. Controlled Circulation with Hypotensive Drugs and Posture to Reduce Bleeding in Surgery. Prelimmary Results with Pentamethonium Iodide. Lancet $i$ : 1145 (1950).

10. Davison, M. H. A. Pentamethonium Iodide in Anaesthesia. Lancet $i$ : 252 (1950).

11. Hunter, A. R. Hexamethonium Bromide. Lancet $i: 251$ (1950).

12. Sadove, M. S.; Wyant, G. M.; \& Gleave, G. Controlled Hypotension. A Study on Arfonad (R02-2222). Anaesthesia 8: 175 (1953).

13. Robertson, J. D. \& Gillies, J. The Use of a Homatropinium Derivative to Produce Controlled Hypotension. Brit. J. Anaesth. 29: 342 (1957).

14. Deacock, A. R. deC. \& Davies, T. D. W. The Influence of Certain Ganglionic Blocking Agents on Neuromuscular Transmission. Brit. J. Anaesth. 30: 217 (1958).

15. Eyre-Walken, D. W. Phenactropinium Chlonde, Clinical Observations. Anaesthesia 16: 74 (1961).

16. Pearcy, W. C \& Wrttenstein, E. S. The Interaction of Trimetaphan (Arfonad), Suxamethonium and Cholinesterase Inhibitor in the Rat. Brit. J. Anaesth. 32: 156 (1960).

17. Endersy, G. E. H. The Advantages of Controlled Hypotension in Surgery. Brit. Med. Bull. 14: 49 (1958).

18. Davison, M. H. A. The Disadvantages of Controlled Hypotension in Surgery. Brit. Med. Bull. 14: 52 (1958).

19. - A New Technique in Hypotension. Anaesthesia 17: 322 (1962). 
20. Grilms, J. General Anaesthesia, vol. 2, p. 40. Evans \& Gray; London: Butterworths (1959).

21. WYKE, B., D. Principles of General Neurophysiology Relating to Anaesthesia and Surgery, 1st ed., p. 97. London: Butterworths (1960).

22. Lynn, R. B.; Sancetta, S. M.; Simeone, F. A.; \& Scott, R. W. Observations on the Circulation in High Spinal Anesthesia. Surgery 32: 195 (1952).

23. Hackel, D. B.; Sancetta, S. M.; \& KLeinERMan, J. Effect of Hypotension due to Spinal Anesthesia on Coronary Blood Flow and Myocardial Metabolism in Man. Circulation 13: 92 (1956).

24. Van Bergen, F. H.; Buckley, M. D.; French, L. A.; Dobken, A. B.; \& Brown, I. A. Physiologic Alterations Associated with Hexamethonium-induced Hypotension. Anesthesiology 15: 507 (1954).

25. Rollason, W. N. \& Cumming, A. R. R. The Electrocardiogram in Hypotensive Anaesthesia. Anaesthesia 11: 319 (1956).

26. Rollason, W. N. \& Hough, J. M. Some Electrocardiographic Studies during Hypotensive Anaesthesia. Brit. J. Anaesth. 31: 66 (1959).

27. Thrower, W. B.; Darby, T. D.; Axdinger, E. E.; \& Sphouse, J. H. Effects of Halothane (Fluothane) Anaesthesia on Ventricular Contractile Force in the Human and Dog. Fed. Proc. 19: 274 (1960).

28. Jornstone, M. The Human Cardiovascular Response to Fluothane Anaesthesia. Brit. J. Anaesth. 28: 392 (1956).

29. DundeE, J. W. \& Black, G. W. A Review of Cardiovascular Effects of Halothane. Anaesthesia 15: 349 (1960).

30. Burn, J. H.; Epstein, H. G.; Fejgan, G. A.; \& Paton, W. D. M. Some Pharmacological Actions of Fluothane. Brit. Med. J. 2: 479 (1957).

31. Burn, J. H. \& Epstein, H. G. Hypotension due to Halothane. Brit. J. Anaesth. 31: 199 (1959).

32. Raventos, J. The Action of Fluothane-A New Volatile Anaesthetic. Brit. J. Pharmacol. 11: 394 (1956).

33. Robinson, J. S. \& Gray, T. C. Observations on the Cerebral Effects of Passive Hyperventilation. Brit. J. Anaesth. 33: 62 (1961).

34. Robinson, J. S. Some Biochemical Effects of Passive Hyperventilation. Brit. J. Anaesth. 33: 69 (1961).

35. Allen, G. D. \& Morris, L. E. Central Nervous System Effects of Hyperventilation during Anaesthesia. Brit. J. Anaesth. 34: 296 (1962).

36. BERG, O.; Nmsson, E.; \& VINNars, E. Investigation of Cerebral Damage Following Induced Hypotension. Brit. J. Anaesth. 29: 146 (1957).

37. Keele, C. A. \& NeIL, E. Samson Wright's Applied Physiology, 10th ed., p. 393. London: Oxford University Press (1961).

38. Muellek, R. P.; LynN, R. B.; \& Sancetta, S. M. Studies of Hemodynamic Changes in Humans following Induction of Low and High Spinal Anaesthesia: Circulation 6: 894 (1952).

39. Greene, N. M.; Bunker, J. P.; Kerr, W. S.; von Felsinger, J. M.; Kelleer, J. W.; \& Beecher, H. K. Hypotensive Spinal Anesthesia: Respiratory, Metabolic, Hepatic, Renal \& Cerebral Effects. Ann. Surg. 140: 641 (1954).

40. Morris, G. C.; Moyer, J. H.; SNyder, H. B.; \& Haynes, B. W. Vascular Dynamics in Controlled Hypotension: A Study of Cerebral \& Renal Hemodynamics and Blood Volume Changes. Ann. Surg. 138: 706 (1953).

41. Evans, B. \& Enderby, G. E. H. Controlled Hypotension and Its Effect on Renal Function.' Lancet $i$ : 1045 (1952).

42. Bromage, P. R. Some Electroencephalographic Changes Associated with Induced Vascular Hypotension. Proc, Roy. Soc. Med. 46: 919 (1953).

43. Saunders, J. W. Effect of Controlled Hypotension on Cerebral Function and Circulation. Lancet $i$ : 1156 (1954).

44. Huches, G. The Investigation of Cerebral Blood Flow during Anaesthesia with Hypotension Induced by the Use of Hexamethonium Bromide and Posture. Brit. J. Anaesth. 27: 229 (1955).

45. Wylie, W. D. \& Chunchill-Davinson, H. C. A Practice of Anaesthesia, chap. 33. London: Lloyd-Luke (1960).

46. Bozza, M. L.; Maspes, P. E.; \& Rossanda, M. The Control of Brain Volume and Tension during Intracranial Operations. Brit. J. Anaesth. 33: 132 (1961). 
47. Hall, L. W. Release of Adrenergic Catechols after the Administration of Hexamethonium Bromide. Brit. J. Anaesth. 29: 294 (1957).

48. LINACRE, J. L. Induced Hypotension in Gynaecological Surgery. Brit. J. Anaesth. 33: 45 (1961).

49. Shepperd, N. L. \& Grace, A. H. Prostatectomy under Hypotensive Anaesthesia. Proc. Roy. Soc. Med. 54: 1127 (1961).

50. Moersch, R. N.; Patrick, R. T.; \& Clagetr, O. T. The Use of Hypotensive Anaesthesia in Radical Mastectomy. Ann. Surg. 152: 911 ( 1960$)$.

51. Murtagh, G. P. Controlled Hypotension with Halothane. Anaesthesia 15: 235 (1960).

52. Vandewater, S. L. The Use of Hypotension and Hypothermia in Subarachnoid Haemorrhage. Pathogenesis and Treatment of Cerebrovascular Disease. Springfield, Ill.: Charles C. Thomas (1961).

53. Tappura, M.; Slatis, M.; \& Troupp, H. Controlled Hypotension in Neurological Surgery. Acta Anaesth. Scand. 5: 47 (1961).

54. ENDERBy, G. E. H. A Report on Mortality and Morbidity Following 9,107 Hypotensive Anaesthetics. Brit. J. Anaesth. 33: 109 (1961).

55. Littze, D. M. Survey of Anesthesiology (Comment) 6: 186 (1962). 